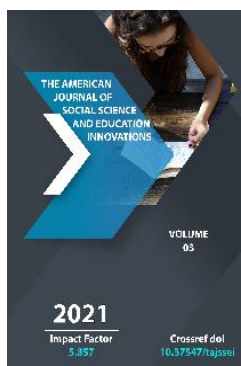

\title{
Gafur Pulatov: The Cry Of Herirud
}

\author{
Sharafutdinov Khursanbay \\ Candidate Of Philological Sciences, Department Of Uzbek Language And Literature, Faculty of \\ Philology, Ferghana State University, Uzbekistan
}

Journal Website:

http://theamericanjour

nals.com/index.php/taj

ssei

Copyright: Original content from this work may be used under the terms of the creative commons attributes 4.0 licence.

\section{ABSTRACT}

The twentieth century, the age of universal discoveries, went down in history as the greatest war in human history - World War II. But in this century, which is not fed up with war, there have been many more wars, big and small. The invasion of Afghanistan by Soviet troops and the military operations there showed that the decline of the army, which had great power as a war that made no sense, was also leading to the disintegration of the world's largest empire. This is what is told in the military-field story "Cry of Herirud".

\section{KEYWORDS}

Herirud, nuclear country, soviet, alliance, "demobee”, "rookie”, coffin, enemy, oppressor, sadism, cannabis, cadet, “junk".

\section{INTRODUCTION}

Period is the author of great discoveries. He also discovers with imagination, even with contemplation. He invented the "flying carpet" with his imagination and invented various flying machines with contemplation. The XX Age of the crossing period brought man to the universe. Indeed, as one of the great practitioners of the period said, the
Earth is indeed the cradle of mankind, but man does not remain in the cradle of mankind. As paradoxical as it may seem, the fact that the period continues to deny its discovery in the same way is a complete reflection of the objective truth. So he is the great judge - Time, affirmation and denial are in his judgment. The most powerful of the empires that have been 
proven over a period of time is the empire that created its power in the literal and figurative sense with the blood of the human body - weakened to cross the twentieth century - Time did not allow; three of the four pillars of the state were cracked: the tall, swollen administration was occupied by cadres who were far from initiative, lowintellectual, but well-versed in what they needed to do in their own interests; the system, wrapped in its own shell, did not bring in advanced technologies that would accelerate the country's development; at one point the development of the economy stagnated. Despite the fact that the first half of the twentieth century became a nuclear country without end, the first decade of the second half of this century took a step towards mastering the universe before the end, and managed to do so, this great power was denied by the Age; according to the wisdom of social nature, truth was decided by the seal of Time. Much has been said and written over the past period about the determination of this truth. "The Cry of Herirud" is a story that is told and written ... The author of this story, Gafur Pulatov, who tells the story of the decline of great power, is a direct participant in the endless war, violence and looting in Afghanistan.

\section{MAIN PART}

The story vividly portrays the relationship between soldiers serving in Afghanistan, which has become a real death knell for both their own people and those who invaded it, as well as the relationship between soldiers in former Soviet military training units.

It is known that everyone is unlikely to return alive from Afghanistan. Everyone knows this, especially the drivers who are transporting troops to the crash site are more aware of the accident. It is also clear from the innumerable degradation of human morality in the Soviet military units that the "driver in the ranks of an ordinary soldier with a Caucasian-looking, dark-white mustache gleaming from the cockpit door of one of the cars", who was transporting the soldiers to the massacre, showed himself, his happiness (not to stay in Afghanistan, the place of death - happiness!), boasting and looking with mockery. It never occurs to him that the young men sent into the fire are soldiers like him, and that he is one of them. Such behavior and attitude can never be expected from the owner, no good thing is expected in any field...

The ridicule, the discrimination, does not end there. As soon as the new soldiers arrive in Afghanistan, they will face such "robbers" again! "We were immediately surrounded by soldiers serving here, their hair and beards growing back, their hair dirty, many of them with mustaches, calling them 'rookies' and asking all sorts of stupid questions. At first, they are interested in what is in our backpack and ask if there is any vodka. When he found out he didn't, he sniffed and said, "What kind of a donkey are these?" There is no vodka in such an alliance. Some began to look at our boots tied to our sacks with their hands. The given new clothes are also pulled by the 'demobees'. "At that moment, someone knocked me down. When I look, the mogul is trying to take off my new boots... I stretch out my arms in that direction, trying to resist.

"Don't be stupid," he said in pure Russian, "I'm lazy, I have to go home."

Apparently, it is unofficially formalized that every soldier transferred from the service to the reserve will change his full uniform in exchange for new conscripts. When this thing is conveyed to one of the officer chiefs, he can shrug his shoulders as if to say "I don't know anything" to the "rookie" complaint. Not only 
that, the platoon commander doesn't even know if his soldier is in place - he is completely unaware of the soldiers sleeping in other places! There will be no more tragedy for the Army.

There is a strong eldership in the relationship between the soldiers. Newcomers to the service - "rookies" must serve as slaves. It is formed as a norm. All the dirty work is on them. Dishwashing, floor washing, bed and toilet cleaning - it's all common work. But this work is entrusted to the newcomers by the elders. The performance of the officers, when evaluated from the same point of view, is zero. Perhaps someone who can fit the whole being into his heart will be tolerant of these things. But what about cleaning the elders' shoes from head to toe, washing their clothes and underwear? How about preparing hot water for their washing and pouring water on their hands and feet has become a rookie's job ?! It is not just that man is being served by man, that he is being raped, that he is being humiliated, that he is directly forgetting his own humanity, turning into a living creature trained to work with an inhuman look, or a robotic machine adapted to it.

Such a life was introduced in the Soviet army in the late 1960s, and became more active in the following decades. In the 80s of the last century, discipline and moral norms were very strict even among the troops inside the country: conscripts from Uzbekistan were returned in coffins instead of alive. The decline of the state system began to accelerate in the same years.

But at the bottom of any darkness there will be light that is nourished by that darkness, it will never disappear absolutely. Because this light - the absence of food - is also a factor in the end of darkness. The enlightenment of the noble is accomplished by struggle. That is why life is always a struggle.

The anguish of the protagonist of the story, who can not bear the pressure of the "elders", leads to a physical explosion - the rookie dares to raise his hand against the elder. "If slavery does not open its eyes, those people are only doomed to slavery" (Chaadaev). At this point, the elder's sternness opens the eyes of the rookie: As soon as we entered the tent, he strangled me and lifted my chin. Burro said he would pull the tongue out with his tag. He then ordered me to take a shovel in my hand, sweep the gravel walkway around the tent and level it. I didn't say a word, but after a while he reappeared next to me. He told me that I did not level the corridor well, that I was not satisfied with my work, and that I did not clean the dishes. I went hot too. In Uzbek, I said, "You are one of us, we are neighbors. How dare you hang me!" - I said.

"I don't know what you're talking about," he said in Russian and slapped it. As the blow subsided, my ears whistled and the sky and the earth exchanged. Thankfully, my physical training worked, and I didn't lose consciousness. I straightened up and, with a shovel in my hand, lowered me to the top of my spine. That's all, yes, you won't fall, you idiot. Indeed, the fact that there is always rebellion in the heart of silence is evident in this movement. The homeland of rebellion is silence, and rebellion matures in its bosom. Rebellion is always a revolt against injustice and all kinds of humiliation. In particular, "a civilized man does harm to himself, but does not humiliate himself"' (Tagore) [11].

Apparently, those who had a strong will be able to stand up to oppression and violence have maintained their courage, especially their human significance and aria, and have always respected these qualities. There were also 
suicides and shifts in what was considered an "enemy". In the story, the weak-willed "dead pigeon Russian boy" who was tortured by the "elders" is fed up with washing "from socks to underwear" and takes the "enemy's " side. In response to a message from the commander that he had "betrayed," a letter came from a mother who had spent her childhood under siege in Leningrad: "I do not have such an innocent son. In fact, the boy would have served. But with whom? Those around him are worse than the enemy, they have lost their appearance, they do not belong to any living thing!

At this point, one aspect draws attention: it is a letter sent as "betrayed". How did the soldier betray, did he refuse to fight for his homeland, did he take the side of the enemy and take part in the invasion of his homeland? Revealed state secrets? In what environment was formed the mind and worldview of a mother who wanted to shoot her child in the forehead? Why does she firmly believe in the letter sent to her child as a traitor?

All this was the work of a strong propaganda, an ideology infused into the minds and consciousness of the people. The absurdity of the ideology has bound many people's minds: the fighters of the national liberation movement that emerged in the Central Asian region are said to be oppressors - oppressors in their homeland! In Afghanistan, Afghans fighting for Afghanistan have been described as "enemies." In Russian, the same word - the word enemy - is actively used.

Franz Mering once echoed Count Manteifel's view: "Almost three-quarters of Germany is full of princes deprived of common sense." No matter how small their state, they imagined that humanity was created for them and that they should serve as the object of their insane misconduct" [5].
It should be noted that the German princes, after all, dreamed of standing in their homeland - Germany. The authors of the new meanings of the words "oppressor" and "enemy" stand in the country of those who speak these words and act, not fantasy military action.

The humiliation of the new conscripts has spread its evil wing widely, not only in the active army, but also in the training units. In these places "the example of sergeants is the ruler, the king; cadets - slaves, robots, live squirrels.

Human thinking may allow some taken man to be shot, hanged, executed as a punishment, but it does not allow humiliation, not even the humiliation of an animal. In the army, which has been active in the wake of the recession, humiliation has become the norm, and many see it as the norm, as do the commanders.

The protagonist of the story catches sight of a frail child collecting cigarette butts in the yard. It is the essence of youth, the "rookie" where honor is destroyed, and the victim of the old age that reigns in the army. There is no greater tragedy in the world. This condition is worse than any humiliation.

It is known that pleasure and relaxation have always been a constant need of the human body and psyche. Rest from pleasant work has always been a human need. Someone enjoys looking at a new plant that he has created, while another creates a new breed of animal... Some people enjoy music, some people enjoy sports, some people enjoy the depths of history. Someone else enjoys fighting animals or birds... In ancient Rome, people were fans of bloody battles, even when there was a fight, which ended in death. It was only when they saw the blood spilled on the arena that their enjoyment was 
satisfied. As Erich From points out, "the complete possession of another person, making him the helpless object of his will, his absolute master - to be God... and enjoying it is the essence of sadism [13]. The means to such a goal is to discriminate and rob him. But the radical way to exercise your power is to torture him. There is no power that can rule over a person more terrible than torturing those who cannot defend themselves."

The blood of these sadists flows in the veins of the sergeants of the Ashgabat training unit, for whom, as the story goes, the "Monkey Game" is enjoyable. In this sense, these sergeants are also going-on sadists, whose skills in this area are very high, with the power to teach ordinary sadists. "Monkey Game" before the night's rest "Sleep!", "Get up!" is physical-physiological suffering by running in the early morning without permission. Finding a flaw in the head-dress inspection during the day and depriving him of breakfast is a torment to wash the dishes until midnight. There is no greater pleasure for drunken sergeants than this torment. If an animal recognizes that someone else in its herd is strong, it pulls itself aside - so that the strong do not attack more. The recognized "strong" immediately stops the attack. "Mr." sergeants, on the other hand, are indifferent to both pleas and kneeling.

The relationship between soldiers and officers is also widely covered in the story. In the context of Afghanistan, the position of most senior officers is not commensurate with their level. When the platoon commander, who had entered one of the tents, cursed and tried to wake the soldiers, one of the beds "voiced": "Slow down, comrade lieutenant, what's the matter, did the sky fall to the ground?" The voice continues, "Comrade Lieutenant, who are these? Rookies?"
As the lieutenant leaves the tent, someone says, "Leytukha, schmuck." The lieutenant himself said, "I'll be back. Is everyone in the platoon?" he asks. Absolute chaos reigns in the platoon: the national anthem is played... To the officer who tries to wake the "sleeping frogs" the soldiers deny, "Uff-f, comrade lieutenant, how cruel, don't even let him lie down." There will be no more tragedy - this is a certain level of denial of the national anthem!

Dirt in the army is also highly negatively assessed by ordinary soldiers. In the eyes of the soldiers, the platoon Vasyutin was recommended as a "downer and softy", but as a "hero", and a unit of the regiment "not a unit, but a mess!" Drug abuse is deeply ingrained among the soldiers. There are so many drug addicts that they want to stay in Afghanistan, which is a death zone for a lifetime, because of this drug addiction. Vagif from Almaty is one of them, because "in his hometown,"junk", cannabis - the seed of junk. Worse, "the Kazakh police are ruthless and uncompromising." One of the worst signs of the declining morale of Soviet soldiers is that they have become a secret military commercial unit in the army, a supplier of drugs, especially construction truck drivers; they do not even think that the acquisition of wealth has blinded them, thrown them into a ravine of spiritual disability, poisoned their countrymen, and sowed the seeds of plague all over the country.

The unit chiefs know everything, but can't go beyond complaining. What distracts them is not discipline and service, but living in the luxury they want, returning to the country with great wealth. The story depicts Soviet officers in a unique way. They are portrayed in one place as military men who do not even have the strength of soldiers, and in another place as people unworthy of their duty. Some 
of them are so illiterate that they cannot show the countries on the map, even those in the military bloc, and political knowledge is not even worth talking about. They are attracted to personal life, interests, and pleasures. Alcoholism, in particular, has become an insurmountable "disease": they drink in exchange for bullets sold to Afghans. Even in times of drunkenness, he orders his soldier: "Find vodka, even if you buy a tank." But there are also many officers who have not lost their human qualities. I regret that one of them chose officer service. He regrets not being able to understand "what the armed forces are" and "having read to the officer without knowing it". He slams himself, the military world to which he belongs: "Oh, Soviet army! Glorious army! The army that defeated the Germans! It's rotting inside now... Do you know why we drank today? For receiving the "Certificate of Honor" as a sample part! Mind you, we're a model part! Hi-hi-hi... Ha-ha-ha... »

Popular words such as "glorious army" that graced the pages of newspapers carry the meaning of ridicule in the tone of this officer's speech. But what the future of Soviet ideology would look like was clearly expressed in the officer's words. "When Lenin died, the whole nation cried, even when Stalin died. No one knew that Khrushchev was dead. When Brezhnev died, the Politburo cried, and when the next secretary general died, only his family cried. "This - one of the officers - is a major in medical poetry. He knows Lermontov's poems by heart. Merry man..."

Apparently, the author of the story did not allow one-sidedness in describing the attitudes, morals and socio-political views of the officers, relying on real life in the image.

The philosophy of the characters in the story is based on the social life in which they grew up. It is this philosophy that moves them. However, the need arising from the demands of life and the existing conditions creates a vibration of views and beliefs. In the struggle against the tragedy that befell or could befall man, the rise of human qualities and values in general to the highest heights is reflected in the story. When these values acquire a universal meaning, they break even some fragile fortresses of faith... There are many examples of such cases in the world and Uzbek literature. For example, when Khamid Olimjon's Roxana was struggling to find a place to bury him, the body of his deceased son, Vova, was embraced by a Muslim cemetery. The old man, the protagonist of the ballad, describes the meaning of the period in two words: "This war has added to the suffering of many peoples, added to their graves."

In the story, the fate of Alexei Rakov, who was poisoned by a mandarin, is expressed in all its warmth, universal qualities. The protagonist of the story brings Alexei to the sanctuary, carries him into the room. When the paramedic told him to leave, he left the room shortly after, wanting to be notified. Then he said, "After lunch, I stretched out to get some relaxation. But before long, I woke up as if someone had pushed me, grabbed my leg, and ran to the medical unit. As I walk down the road, I wonder to myself. "Why shouldn't I be so upset, when he is second cousin twice removed?" I had to bring him to the medical unit, I brought him. What else can I do?". But a stubborn instinct pushed me to go to him, and I pushed forward, obeying his command. Perhaps, regardless of our nationality or religion, the horrors of war that have befallen us have brought us closer together. The feeling that led me to the Russian guy was probably this feeling of closeness and sympathy... » 
This feeling, this worldview, is rooted in the mind and heart due to the realization of humanity, a kind of belonging to the human being, which is higher than narrow national and religious-religious views on the scale of thinking.

In the philosophical structure of the story, in connection with the course of events, changes in the worldview of the characters are also reflected in the thoughts of the protagonist. "Aren't we all the same here? Could it be that the tragic tragedy of someone whose religion is different, blonde hair now makes me think differently? Let the house burn down in such a war!"

The psychology of the protagonists of the story is closely connected with the social content of the existing conditions. This can be seen when the feeling of pity in the driver of the construction avtobatalion is completely gone. They see the deathbed as a market. Drivers of troops to Afghanistan, aware of the tragic fate of the soldiers, laugh at them in their brains. Mercy reigns in inter-military relations. In the vernacular, the stubborn 'elder' soldiers rejoice in the torment of the new conscripts - the suffering of others is joy, not pity for others! The impoverishment of the human heart, expressed in a text, is expressed in a single sentence of a driver who carries water to the highest points: I didn't do it.

It is a certain kind of evil of the spiritual image of man. At the same time, cruelty and savagery are even stronger among officers. They do not know how to show mercy to the unarmed population - women and children. In particular, the shooting of a driver-taxi driver in a collision with an APC shows that in the heart of the officer, the kindness, kind feelings have disappeared without a trace.
A few days later, the protagonist of the story goes to the paramedic who received the Russian soldier Alexei and asks:

- A few days ago I brought a poisoned soldier? - I ask a familiar paramedic. - First name Alexey, last name...

"Oh, he is," he said, yawning carelessly and pointing to the ceiling. "He's already on his way to the "throne."

There is no expression of sadness or sympathy on his weary face. On the contrary, there was an insensitive feeling in his face, as if it were about an animal. I was so angry that I could barely contain myself and asked again:

- Three or four days ago a friend was brought in with pneumonia and fever?

My question remained in my mouth. Paramedic said in anger:

"The last thousand." How do I know which one is your friend? Or is it written on his forehead ?! Look inside, and if he is not dead, you will find him.'

These words are not only the words of a person who is aware of a medical oath, but also the words of someone who has taken that oath.

The author uses various methods and tools to describe the psyche of the heroes. Dreaming is one of them.

"My eyes closed on their own, I fell asleep and started dreaming. Well, my grandmother is baking bread in the oven. I have a wonderful grandmother though. He never trusts anyone to do his job. He also bakes bread himself, but he also makes very tasty bread. I reach for the crimson loaves in the basket as I taste the crunchy breads my grandmother baked. Now, 
when I say take it, instead of bread, there are blood-stained, grinning heads in the basket. I woke up screaming in horror."

There is no other dream in Death Valley...

The social content of the period, the requirements of this period, the rules that must be unconditionally accepted, do not allow the manifestation of good qualities, beautiful qualities in the human psyche. As long as it is in constant motion, Time will continue to discover its own laws and rules. It is on the basis of this consciousness and spirituality that these discoveries are sealed and "poured" into people's minds and views, into their spiritual world.

One of the protagonists of the story is a young man who is in fact strong-willed, art-loving and has a beautiful heart. But this soldier was well infected with the social 'disease' of his service. He became famous for his violence among his colleagues. This young man always uses the services of other soldiers - caves, plays the guitar and sings to the young man from Leningrad, listens to him "with his feet in the air."

The real heart of this young man opens when he asks the protagonist for a song.

"Brother, can you sing me a song?" "What's the matter, he seems to be trying to get me to join the Leningrad boy," I thought. For a moment I was a little distracted and awake.

"I don't know how to sing," I told him without losing my temper.

"There's never been a man who hasn't sung in his life." Well, at least you didn't go down without explaining yourself first. Well, say it in your name, even if you say something. After all, our languages are also close to each other.
The most important thing is to say from the heart, let's have some fun. "

Apparently, the scary guy knows the nations that are related to him, so awareness is no stranger. He enjoys listening to the songs of both Leningrad and Fergana, which means that the relative breadth of artistic and aesthetic taste is good. But these qualities of his live in a neighborhood with inhuman flaws. Because he, like many others, is ruthless

in his role as an "elder," an "eye." Such psychology has been nurtured in his heart and soul by the demands of time and social conditions. He has gained a "reputation" for his practical work in major thefts with his bosses, which is why he is always in the forefront of bosses. Such a division of the spiritual world has become almost legitimate in the environment in which he breathes. It is this legitimacy that has formed absoluteness in every action of the savage, and this absoluteness has made him a citizen of the world of savagery. But the Leningrad singer, who opened his eyes to slavery, gives his impression. "Trump" does not fit into his team. Considering it a shame to fall from the "eye", he is forced to leave the point to which he belongs.

Not all of the people portrayed in the story were born bad, but the social content of the period enlarged and reshaped them in a unique way. The continuity of time, the uneven movement of society in the areas described in the play, created a sociophilosophical, spiritual world that is unique to this region, and on this basis revealed unwritten moral norms, relationships and attitudes between people. If in the last quarter of the 15th century, the sultans of Egypt and Syria said, based on the social context of their time, "we - the kings - stand above the laws of the world, not outside 
them" (V. Mutafchieva), by the twentieth century, the great power ignored all laws, he sealed every wish of his as law [7]. But the seal of the Age, the discovery of time, is always objective - it is not subject to anyone's will! This time it was the same.

\section{CONCLUSION}

It is well known that fiction has an active, vivid effect on human thinking. It performs a number of social functions with the same feature. Education and upbringing in the art of artistic expression is one such task. The role of literature in the understanding of man's identity, in his perception that he is a higher being called man, as well as in his understanding that he is a child of a certain nation spiritually, socially and philosophically, is unique. With these aspects, literature serves for national formation. Every person belonging to a nation formed as a nation feels and feels itself a part of the Homeland, and understands the Homeland as its own huge home that continues beyond the threshold, there is nothing foreign in it, everything in it is mine, and I belong to it; the child of a nation formed as a nation understands this through contemplation and perception, places it in his mind, pours it into his heart with his feelings. From this point of view, the role of the "Cry of Herirud" in the formation and development of social identity is equally important for both adults and young people. This work is also valuable in Uzbek literature as a unique military field story [15].

\section{REFERENCES}

1. Barbyus A. (1978). O bor'be protiv voennoy opasnosti i o yubilee
A.M.Gor'kogo. Pisateli Fransii o literature. M. Progress.

2. Karpent'er A. (1982). Samosoznanie i sushnost' Latinskoy Ameriki. Pisateli Latinskoy Ameriki o literature. M. Raduga.

3. Krishnamurtiy DJ. (1987). Kommentarii $k$ jizni. Otkritie Indii. $M$. Xudojestvennaya literatura.

4. Mering F. (1985). Izbrannie trudi po estetike. Tom I. M. Iskusstvo.

5. Mering F. (1985). Izbrannie trudi po estetike. Tom II. M. Iskusstvo.

6. Migel' A.A. (1982). Latinoamerikanskiy roman - svidetel'stvo epoxy. Pisateli Latinskoy Ameriki o literature. M. Raduga.

7. Mutafchieva V. (1988). Delo sultana Djema. Sofiya: "Svyat".

8. Neru Dj. (1989). Otkritie Indii. Kniga pervaya. M. izd. politicheskoy literaturi.

9. Neru Dj. (1989). Otkritie Indii. Kniga vtoraya. M. izd. politicheskoy literaturi.

10. Svas'yan K.A. (1989). logann Vol'fgang Gyote. M. "Misl'”.

11. Tagor R. (1987). Sadxona. Problema zla. Otkritie Indii. M. "Xudojestvennaya literatura".

12. Tagor R. (1987). Zayavlenie po povodu nachala vtoroy mirovoy voyni. Otkritie Indii. M. Xudojestvennaya literatura.

13. From E. (2009). Begstvo ot svobodi. M. Ast Moskva.

14. Xandruev A.A. (1990). Gegel'. M. "Ekonomika".

15. Sharafiddinov X. (2014). Masallarda ozodlik va erk g'oyasi. Qat'iyat. "Farg'ona". 